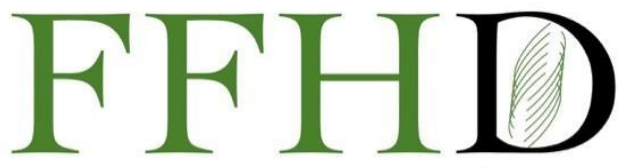

Functional Foods in Health and Disease

\title{
Brazilian green propolis promotes the cytoprotective expression of heme oxygenase-1 against oxidative stress injury in murine myoblast cells
}

\author{
Naoki Chinen ${ }^{1}$, Wataru Otsu' ${ }^{2, *}$, Kazuki Ohuchi ${ }^{1}$, Shiori Ando ${ }^{1}$, Shinsuke Nakamura ${ }^{1}$, Hiroyuki \\ Kono $^{3}$, Masamitsu Shimazawa ${ }^{1,2}$, and Hideaki Hara ${ }^{1,2}$ \\ ${ }^{1}$ Department of Biofunctional Evaluation, Molecular Pharmacology; ${ }^{2}$ Department of Biomedical Research Laboratory \\ Gifu Pharmaceutical University, 1-25-4 Daigakunishi, Gifu, 501-1196 Japan; ${ }^{3}$ Nagaragawa Research Center, API Co., \\ Ltd., Gifu, 502-0071, Japan.
}

*Corresponding Author: Wataru Otsu, DVM., Ph.D., Department of Biomedical Research Laboratory Gifu Pharmaceutical University, 1-25-4 Daigakunishi, Gifu, 501-1196 Japan.

Submission Date: October 26 ${ }^{\text {th }}, 2020$; Acceptance Date: December $2^{\text {nd }}, 2020$; Publication Date: December $16^{\text {th }}, 2020$

Please cite this article as: Chinen N., Otsu W., Ohuchi K., Ando S., Najkamura S., Kono H., Shimazawa M., Hara H. Brazilian green propolis promotes the cytoprotective expression of heme oxygenase- 1 against oxidative stress injury in murine myoblast cells. Functional Foods in Health and Disease 2020. 10(12): 493-504. DOI: https://www.doi.org/10.31989/ffhd.v10i12.756

\section{ABSTRACT}

Background: Sarcopenia is a progressive skeletal muscle disorder characterized by the progressive loss of muscle mass and function, resulting in physical disability and mortality. Although sarcopenia impacts a large proportion of elderly individuals, no effective treatment for this disease has yet been identified. The excessive production of reactive oxygen species (ROS) can damage tissues and promote aging, and the daily use of dietary antioxidants can be effective for maintaining skeletal muscle health.

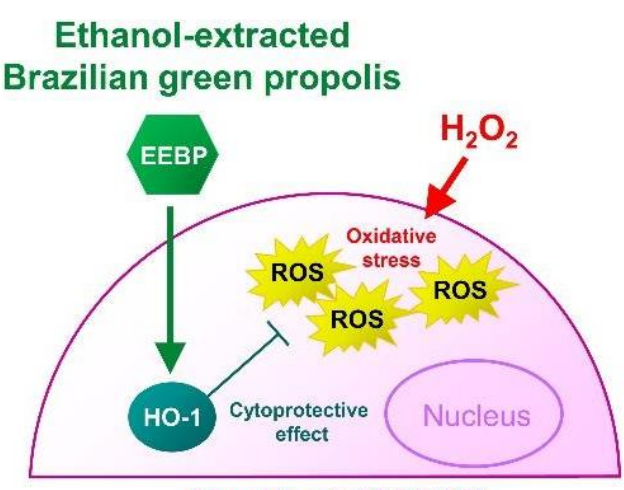

Myoblast (C2C12) Propolis, a natural substance that is collected by honey bees, has been used as traditional medicine, and many reports have described its antioxidative properties. However, how propolis exhibits cytoprotective effects and antioxidative effects in skeletal muscles remains unclear. The purpose of this study was to investigate the 
antioxidative effects of ethanol-extracted Brazilian green propolis (EEBP, from Baccharis dracunculifolia) and its three constituents using an in vitro myoblast cell model.

Methods: Murine myoblast C2C12 cells were treated with either EEBP or its constituents, including caffeic acid, trans-ferulic acid, and p-coumaric acid, in the presence of 100 or $300 \mathrm{mM} \mathrm{H}_{2} \mathrm{O}_{2}$ to induce oxidative stress injury. The cell death ratio and cell viability were assessed by Hoechst 33342 and propidium iodide staining and the WST8 assay, respectively. Simultaneously, intracellular ROS production was measured by CM- $\mathrm{H}_{2}$ DCFDA [5-(and-6)chloromethyl-2',7'-dichlorodihydrofluorescein diacetate, acetyl ester] assay. Finally, immunoblotting was performed in myoblast cell lysates to assess the expression level of an antioxidative enzyme, heme oxygenase-1 (HO-1).

Results: We demonstrated that EEBP significantly reduced $\mathrm{H}_{2} \mathrm{O}_{2}$-induced cell death at a concentration of $3 \mu \mathrm{g} / \mathrm{ml}$ in myoblasts. Additionally, caffeic acid at $100 \mu \mathrm{M}$ improved cell viability under oxidative stress conditions, but not trans-ferulic acid or p-coumaric acid. Both EEBP and caffeic acid inhibited the $\mathrm{H}_{2} \mathrm{O}_{2}$-induced increase in ROS production. Finally, HO-1 expression was increased by treatment with either EEBP or caffeic acid. The increase in HO-1 expression induced by $\mathrm{H}_{2} \mathrm{O}_{2}$ was enhanced in the presence of EEBP and caffeic acid.

Conclusions: These findings indicated that EEBP has protective effects against oxidative damage in the C2C12 murine myoblast cell line. Caffeic acid is an EEBP constituent that contributes to cytoprotective activity. EEBP may act as an inducer of HO-1 to prevent oxidative stress-induced myoblast death.

Keywords: C2C12 murine myoblast cells, heme oxygenase-1, oxidative stress, propolis, reactive oxygen species CFFC 2020. This is an Open Access article distributed under the terms of the Creative Commons Attribution 4.0 License (http://creativecommons.org/licenses/by/4.0)

\section{INTRODUCTION}

Sarcopenia is a progressive and generalized skeletal muscle disorder that increases the likelihood of negative outcomes, such as falls, fractions, physical disability, and mortality [1]. Sarcopenia progression is characterized by the significantly reduced regenerative potential of muscle fibers due to a reduced pool of satellite cells, which are responsible for muscle regeneration at damaged sites through myogenic differentiation into skeletal myoblasts [2]. The population size and the function of satellite cells are deteriorated by oxidative stress, which increases with aging. Aged satellite cells exhibit declining antioxidative capacity and increased levels of reactive oxygen species (ROS) [3]. Age-related mitochondrial DNA damage leads to mitochondrial dysfunction, and aging muscle cells have the impaired ability to remove these dysfunctional mitochondria, resulting in increased ROS production and oxidative damage [4]. Chemicals with antioxidative activities might be potential candidates for slowing or stopping the progression of sarcopenia by attenuating age-related 
increases in ROS production and maintaining the myosatellite pool.

Propolis is a well-known traditional medicine that has been used since ancient times worldwide, especially in Eastern Europe and Brazil [5]. Propolis is produced from a resinous substance collected by honeybees from the sprouts and bark of various plants. Therefore, the constituents of propolis depend on its geographic origins, and the biological activity of propolis not necessarily consistent [6]. Brazilian green propolis has been reported to have various biological activities, such as antibacterial [6], anti-inflammatory [7], antioxidative [8], tumoricidal [9], and neuroprotective activities [10]. Its substances and biological activities also depend on the extraction method used. Ethanol-extracted Brazilian green propolis (EEBP) contains numerous chemical ingredients, including cinnamic acid derivatives, such as artepillin C, and hydroxycinnamic acids, such as caffeic acid, ferulic acid, and p-coumaric acid [11], which have been reported to exert inhibitory effects against low-density lipoprotein oxidation [12]. However, the biological activities of these constituent chemicals in skeletal muscles have not been wellstudied.

Nuclear factor erythroid 2-related factor (Nrf2), a master regulator of intracellular antioxidative responses, is required for muscle endurance performance and mitochondrial function in skeletal muscles [13]. In addition, Nrf2 activity has been reported to facilitate muscle regeneration [14]. The Nrf2 and Kelch-like ECH-associated protein 1 (Keap1) pathway regulate intracellular redox homeostasis through the nuclear transport of Nrf2, allowing for Nrf2 to interact with the promoter regions of genes encoding antioxidant enzymes, such as heme oxygenase-1 (HO-1) [15]. Recently, we reported that the water-extracted propolis activates the antioxidant response element (ARE), resulting in the upregulation of HO-1 expression, which mediated cytoprotective effects under oxidative stress conditions [16]. These findings led us to question whether EEBP could induce a similar antioxidative response through Nrf2-mediated HO-1 activation in myoblasts.

Here, we investigated the cytoprotective activity of EEBP in murine myoblast $\mathrm{C} 2 \mathrm{C} 12$ cells. We examined cell death and viability following the induction of oxidative stress using $100 \mu \mathrm{M} \mathrm{H}_{2} \mathrm{O}_{2}$. We also tested the constituents of the EEBP, including trans-ferulic acid, caffeic acid, and p-coumaric acid. Then, we analyzed the effects of EEBP and caffeic acid on ROS production under oxidative stress conditions. Finally, we performed immunoblotting to understand EEBP-associated signaling pathways.

\section{MATERIALS AND METHODS}

Materials: Ethanol-extracted Brazilian green propolis (EEBP) was prepared as follows. A lump of Brazilian green propolis from Baccharis dracunculifolia (Nubas Gerais State, Brazil) was crushed, soaked in $95 \%$ ethanol, and stirred for $24 \mathrm{~h}$ at room temperature, after which the propolis grounds were removed by filtration. The filtrate was stored at $-20^{\circ} \mathrm{C}$ for more 
than $24 \mathrm{~h}$, and the insoluble matter was removed by filtration. The ethanol-extracted solution was prepared by adjusting its solid content to $55 \%(\mathrm{w} / \mathrm{w})$. trans-Ferulic acid and caffeic acid were purchased from Tokyo Chemical Industry Co., Ltd. (TCl; Tokyo, Japan). $p$-Coumaric acid was purchased from SigmaAldrich (St. Louis, USA).

Cell Viability and Cell Death Assays: C2C12 murine myoblast cells were maintained in a growth medium consisting of DMEM, 10\% FBS, $100 \mathrm{U} / \mathrm{mL}$ penicillin (Meiji Co., Ltd., Tokyo, Japan), and $100 \mu \mathrm{g} / \mathrm{mL}$ streptomycin (Meiji Co., Ltd.), as described previously [17]. Cells were seeded into 96-well plates (BD Biosciences, Franklin Lakes, NJ, USA) at a density of 5,000 cells per well and incubated for $24 \mathrm{~h}$ at $37^{\circ} \mathrm{C}$. EEBP was dissolved in dimethyl sulfoxide (DMSO; Nacalai Tesque) and diluted with phosphate-buffered saline (PBS; $\mathrm{KCl}: 0.2 \mathrm{mg} / \mathrm{ml}, \mathrm{KH}_{2} \mathrm{PO}_{4}: 0.24 \mathrm{mg} / \mathrm{ml}$, $\mathrm{NaCl}: 8 \mathrm{mg} / \mathrm{ml}$ and $\mathrm{Na}_{2} \mathrm{HPO}_{4} / 12 \mathrm{H}_{2} \mathrm{O}: 3.63 \mathrm{mg} / \mathrm{ml}$ ) to obtain the desired final concentration of $\operatorname{EEBP}(1,3$, or $10 \mu \mathrm{g} / \mathrm{ml})$. DMSO (0.1\%), EEBP, caffeic acid (1, 10, or $100 \mu \mathrm{M})$, trans-ferulic $(1,10$, or $100 \mu \mathrm{M}), p$ coumaric acid $(1,10$, or $100 \mu \mathrm{M})$ at the indicated concentrations were added to the culture medium. One hour after chemical addition, $100 \mu \mathrm{M}$ or $300 \mu \mathrm{M}$ $\mathrm{H}_{2} \mathrm{O}_{2}$ was added to the cell culture, followed by incubation for $6 \mathrm{~h}$ or $24 \mathrm{~h}$. Cell viability and cell death assays were performed according to the manufacturer's instructions.

Cell viability was measured by using the Cell Counting Kit-8 (CCK-8; Dojin Kagaku, Kumamoto,
Japan). A CCK-8 reagent containing WST-8 was added to each well at $10 \mu \mathrm{l}$ and incubated $2 \mathrm{~h}$. Subsequently, the absorbance was measured by using the Varioskan Flash 2,4 microplate reader (Thermo Fisher Scientific, Waltham, MA, USA) at $450 \mathrm{~nm}$.

The cell death rate was measured by double staining with Hoechst 33342 (Invitrogen, Carlsbad, CA, USA) and propidium iodide (PI; Invitrogen). After incubation, Hoechst 33342 and PI were added to each well at final concentrations of $8.1 \mu \mathrm{M}$ and $1.5 \mu \mathrm{M}$, respectively. Images were obtained by Lionheart FX (BioTek Winooski, Vermont, USA) and analyzed by Gen5 software (Bio Tek Instruments).

ROS production assay: To measure ROS production, 5-(and-6)-chloromethyl-2', $7^{\prime}$

dichlorodihydrofluorescein diacetate, acetyl ester (CM- $\mathrm{H}_{2}$ DCFDA, Thermo Fisher Scientific) was used as an intracellular ROS indicator. $\mathrm{CM}-\mathrm{H}_{2} \mathrm{DCFDA}$ solution was added to the cell culture at a final concentration of $10 \mu \mathrm{M}$ and incubated at $37^{\circ} \mathrm{C}$ for $1 \mathrm{~h}$. Fluorescent signals were measured by using a microplate reader (Varioskan Flash 2,4, Thermo Fisher Scientific) at ex/em: 485/535 $\mathrm{nm}$. The ROS production rate was adjusted by the cell number, which was determined based on Hoechst 33342 staining.

Western blotting analysis: Western blotting was carried out as described previously [17]. Briefly, cells were seeded on a 12-well plate at a density of 100,000 cells per well and incubated for $24 \mathrm{~h}$. After the addition of EEBP ( 1 or $10 \mu \mathrm{g} / \mathrm{ml}$ ), caffeic acid (100 
$\mu \mathrm{M})$, trans-ferulic $(100 \mu \mathrm{M}), p$-coumaric acid (100 $\mu \mathrm{M})$, and $\mathrm{H}_{2} \mathrm{O}_{2}(100 \mu \mathrm{M})$, the cells were incubated for an additional $6 \mathrm{~h}$. Then, the cells were washed with ice-cold PBS and lysed in radioimmunoprecipitation assay (RIPA) buffer (R0278; Sigma-Aldrich, St. Louis, Mo, USA), supplemented with a protease inhibitor cocktail (Sigma-Aldrich) and phosphatase inhibitor cocktails 2 and 3 (Sigma-Aldrich). Protein concentrations were measured with a BCA Protein Assay Kit (Thermo Fisher Scientific). An equal volume of protein lysate and sample buffer solution (FUJIFILM-Wako Pure Chemical Co., Osaka, Japan) were combined and boiled for $5 \mathrm{~min}$. The protein samples were separated on a $5 \%-20 \%$ gradient sodium dodecyl sulfate (SDS)-polyacrylamide gel (SuperSep Ace; FUJIFILM-Wako Pure Chemical Co.) and transferred to a polyvinylidene difluoride membrane (Immobilon-P; Merck Millipore, Billerica, MA, USA). After blocking with Blocking One-P (Nacalai Tesque), the membranes were incubated with antiHO-1 antibody (rabbit, sc-10789, Santa Cruz, Dallas, TX, USA; $1: 200$ ) and anti- $\beta$-actin antibody (mouse, A2228, Sigma-Aldrich; $1: 2000$ ) in a cold room at $4^{\circ} \mathrm{C}$ for overnight, followed by further incubation with horseradish peroxidase (HRP)-conjugated goat antirabbit or anti-mouse IgG (Thermo Fisher Scientific; $1: 2,000)$ at room temperature for $1 \mathrm{~h}$. Immunoreactive bands were visualized by Immunostar-I.D (FUJIFILM-Wako Pure Chemical Co.) and detected using an Amersham Imager 680 (GE Healthcare, Chicago, IL, USA). The signal intensity was analyzed by Amersham Imager 680 software (GE Healthcare) and the signal intensity was normalized against that of $\beta$-actin.

Statistical analysis: All data represent the mean \pm standard error of the mean (SEM). Statistical analyses were performed by either Student's $t$-test or Dunnett's test, using SPSS Statistics software (IBM, Armonk, NY, USA). A $p<0.05$ indicated statistical significance.

\section{RESULTS}

Protective effects of EEBP in an in vitro murine myoblast cell oxidative stress model: To investigate the effects of EEBP on myoblasts, we used $\mathrm{C} 2 \mathrm{C} 12$ cells as an in vitro model. $\mathrm{C} 2 \mathrm{C} 12$ cells were incubated with $100 \mu \mathrm{M} \mathrm{H} \mathrm{H}_{2} \mathrm{O}_{2}$ for $6 \mathrm{~h}$ to induce oxidative stress. As reported previously [18], $\mathrm{H}_{2} \mathrm{O}_{2}$ exposure for $6 \mathrm{~h}$ significantly decreased cell viability among C2C12 cells (Fig. 1A). Subsequently, both $3 \mu \mathrm{g} / \mathrm{mL}$ and 10 $\mu \mathrm{g} / \mathrm{mL}$ of EEBP improved cell viability, but $1 \mu \mathrm{g} / \mathrm{mL}$ of EEBP did not (Fig. 1A). In parallel, we confirmed that neither 1 nor $10 \mu \mathrm{g} / \mathrm{mL}$ of EEBP caused obvious toxicity (Fig. 1B). Oxidative stress triggers apoptosis [19], and the cell death rate increased following exposure to $100 \mu \mathrm{M} \mathrm{H}_{2} \mathrm{O}_{2}$ for $6 \mathrm{~h}$, as expected. EEBP treatment significantly suppressed cell death in a dose-dependent manner (Fig. 1C and D). These results suggested that EEBP exerts protective effects against $\mathrm{H}_{2} \mathrm{O}_{2}$-induced oxidative stress injury in myoblast cells. 

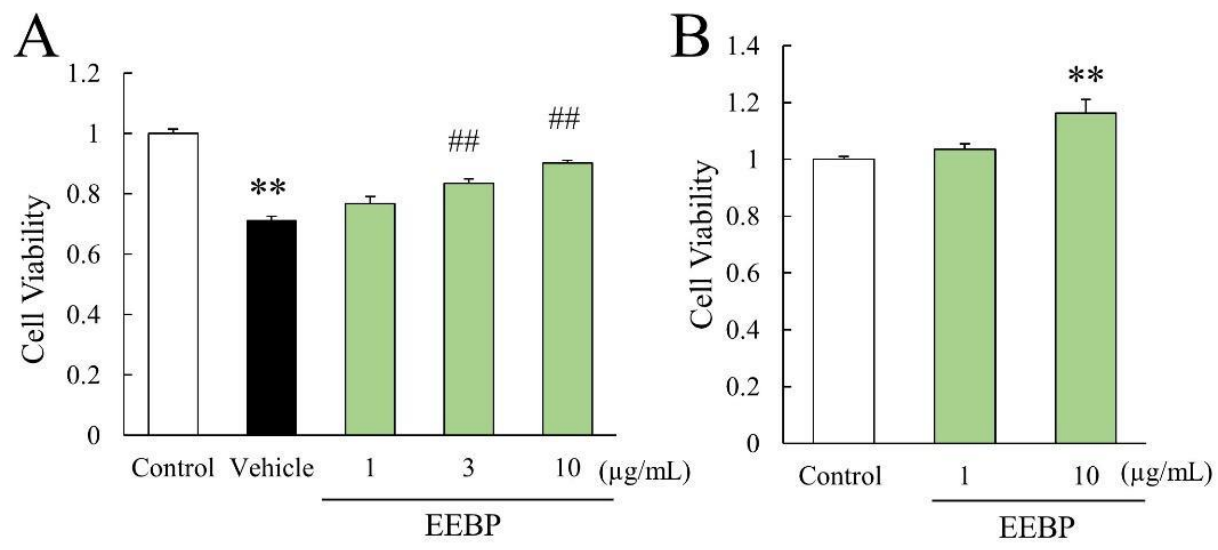

$100 \mu \mathrm{M} \mathrm{H}_{2} \mathrm{O}_{2}$

C

Hoechst / Propidium Iodide
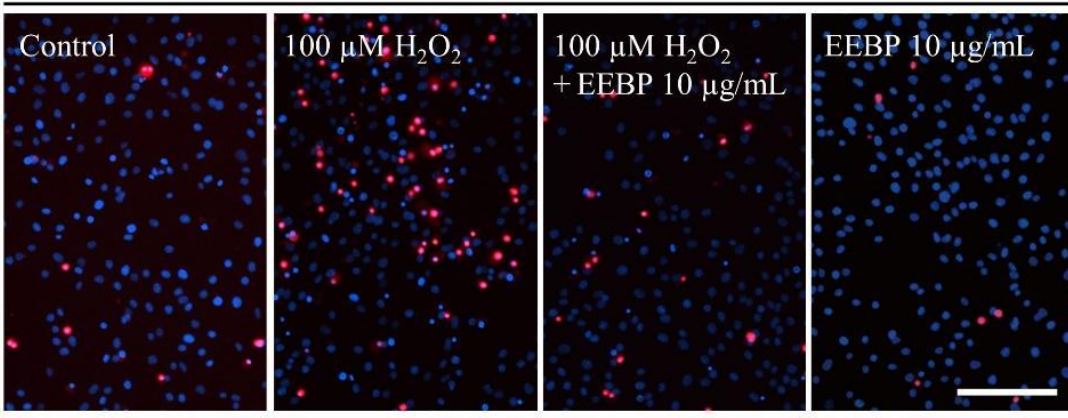

$\mathrm{D}$

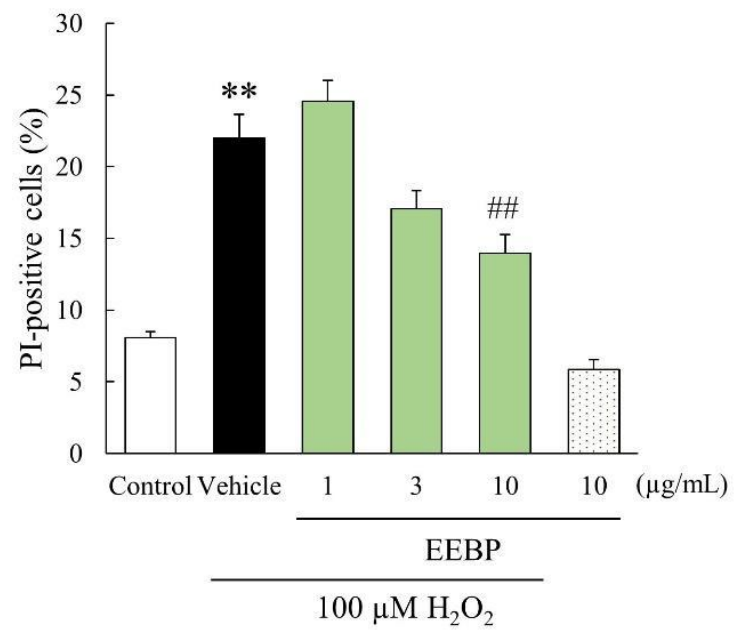

Figure 1 Effects of ethanol-extracted Brazilian green propolis on hydrogen peroxide-induced oxidative damage in myoblasts. (A) Bars represent the fold increase in cell viability, as measured by CCK-8 assay, following exposure to $100 \mu \mathrm{M} \mathrm{H}_{2} \mathrm{O}_{2}$ in $\mathrm{C}_{2} \mathrm{C} 12$ cells treated with either $1 \mu \mathrm{g} / \mathrm{mL}, 3 \mu \mathrm{g} / \mathrm{mL}$, or $10 \mu \mathrm{g} / \mathrm{mL}$ of ethanol-extracted Brazilian green propolis (EEBP) for $6 \mathrm{~h}$. (B) Cell viability was measured to examine EEBP toxicity. C2C12 cells were incubated without $\mathrm{H}_{2} \mathrm{O}_{2}$ exposure in the absence or presence of either $1 \mu \mathrm{g} / \mathrm{mL}$ or $10 \mu \mathrm{g} / \mathrm{mL}$ of EEBP. (C) Representative live images of Hoechst 33342 (blue) and propidium iodide ( $\mathrm{Pl}$, red) staining in $\mathrm{C} 2 \mathrm{C} 12$ cells treated with or without EEBP and $\mathrm{H}_{2} \mathrm{O}_{2}$. Scale bar, $200 \mu \mathrm{m}$. (D) The number of PI-positive cells was counted and presented as a cell death ratio. Data are shown as the mean \pm SEM $(N=5-6) .{ }^{*} P<0.05,{ }^{* *} P<0.01$, Student's $t$-test vs. Control, ${ }^{*} P<0.05,{ }^{\# \#} P<0.01$, Dunnett's test vs. Vehicle. 
The protective effects of caffeic acid in an in vitro oxidative stress model: To identify which chemical constituent(s) of EEBP are associated with the observed protective effect against oxidative stress, we chose and examined three substances found in EEBP: caffeic acid, trans-ferulic acid, and $p$-coumaric acid (Fig. 2A). Only caffeic acid significantly improved cell viability of $\mathrm{C} 2 \mathrm{C} 12$ cells treated with $\mathrm{H}_{2} \mathrm{O}_{2}$ at a concentration of $300 \mu \mathrm{M}$, whereas neither transferulic acid nor $p$-coumaric acid exhibited any effects on cell viability (Fig. 2B), suggesting that caffeic acid may contribute to the protective effects observed for EEBP against oxidative stress injury in myoblasts.<smiles>O=C(O)/C=C/c1ccc(O)c(O)c1</smiles>

Caffeic acid<smiles>O=C(O)/C=C/c1ccc(O)cc1</smiles><smiles>COc1cc(/C=C/C(=O)O)ccc1O</smiles>

trans-Ferulic acid

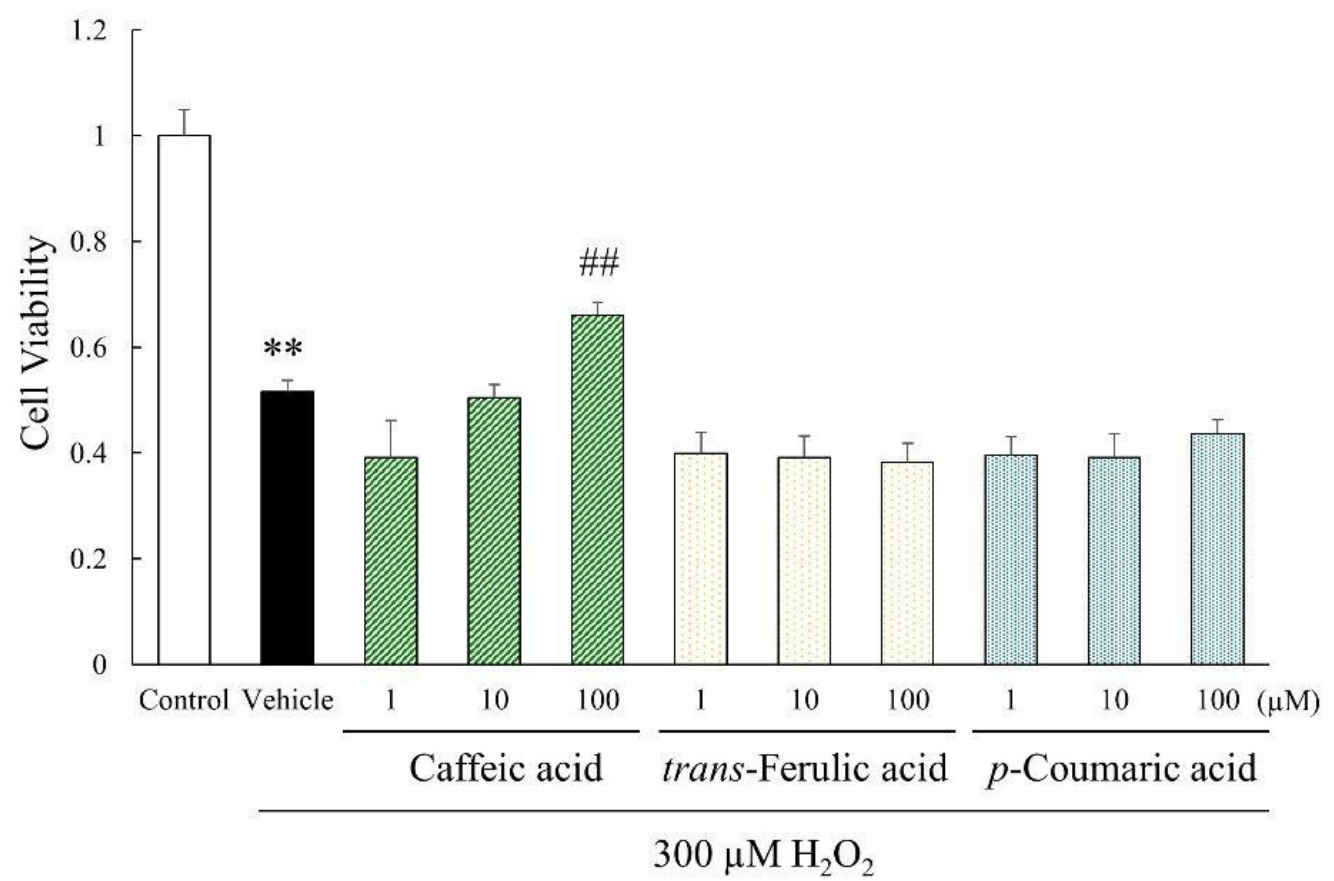

Figure 2. Examination of propolis constituents in a myoblast hydrogen peroxide-injury model. (A) The chemical structures of the examined compounds, caffeic acid, trans-ferulic acid, and $p$-coumaric acid. (B) Bars show the fold increase in cell viability following exposure to $300 \mu \mathrm{M} \mathrm{H}_{2} \mathrm{O}_{2}$ for $24 \mathrm{~h}$ in $\mathrm{C}_{2} \mathrm{C} 12$ cells treated with either caffeic acid (1 $\mu \mathrm{M}, 10 \mu \mathrm{M}$, or $100 \mu \mathrm{M})$, trans-ferulic acid $(1 \mu \mathrm{M}, 10 \mu \mathrm{M}$, or $100 \mu \mathrm{M})$, or $p$-coumaric acid $(1 \mu \mathrm{M}, 10 \mu \mathrm{M}$, or $100 \mu \mathrm{M})$. Data are shown as the means \pm SEM $(\mathrm{N}=5) .{ }^{* *} P<0.01 \mathrm{vs}$. Control (Student's $t$-test), ${ }^{\#} P<0.01 \mathrm{vs}$. Vehicle (Dunnett's test). 


\section{The Mechanism for EEBP antioxidative activity in an} in vitro oxidative stress model: To investigate the antioxidative activity of EEBP and caffeic acid, we measured intracellular ROS production. The levels of intracellular ROS were measured using $\mathrm{CM}-\mathrm{H}_{2}$ DCFDA after EEBP treatment and $\mathrm{H}_{2} \mathrm{O}_{2}$ exposure. As expected, $\mathrm{H}_{2} \mathrm{O}_{2}$ exposure increased ROS production, whereas EEBP attenuated this increase in ROS at concentrations of 3 and $10 \mu \mathrm{g} / \mathrm{mL}$, but not at $1 \mu \mathrm{g} / \mathrm{mL}$ (Fig. 3A). In addition, 1, 10, and $100 \mu \mathrm{M}$ caffeic acid significantly decreased ROS production (Fig. 3B). These results indicate that EEBP and its constituent, caffeic acid can prevent ROS production under the condition of $\mathrm{H}_{2} \mathrm{O}_{2}$ induced oxidative stress.
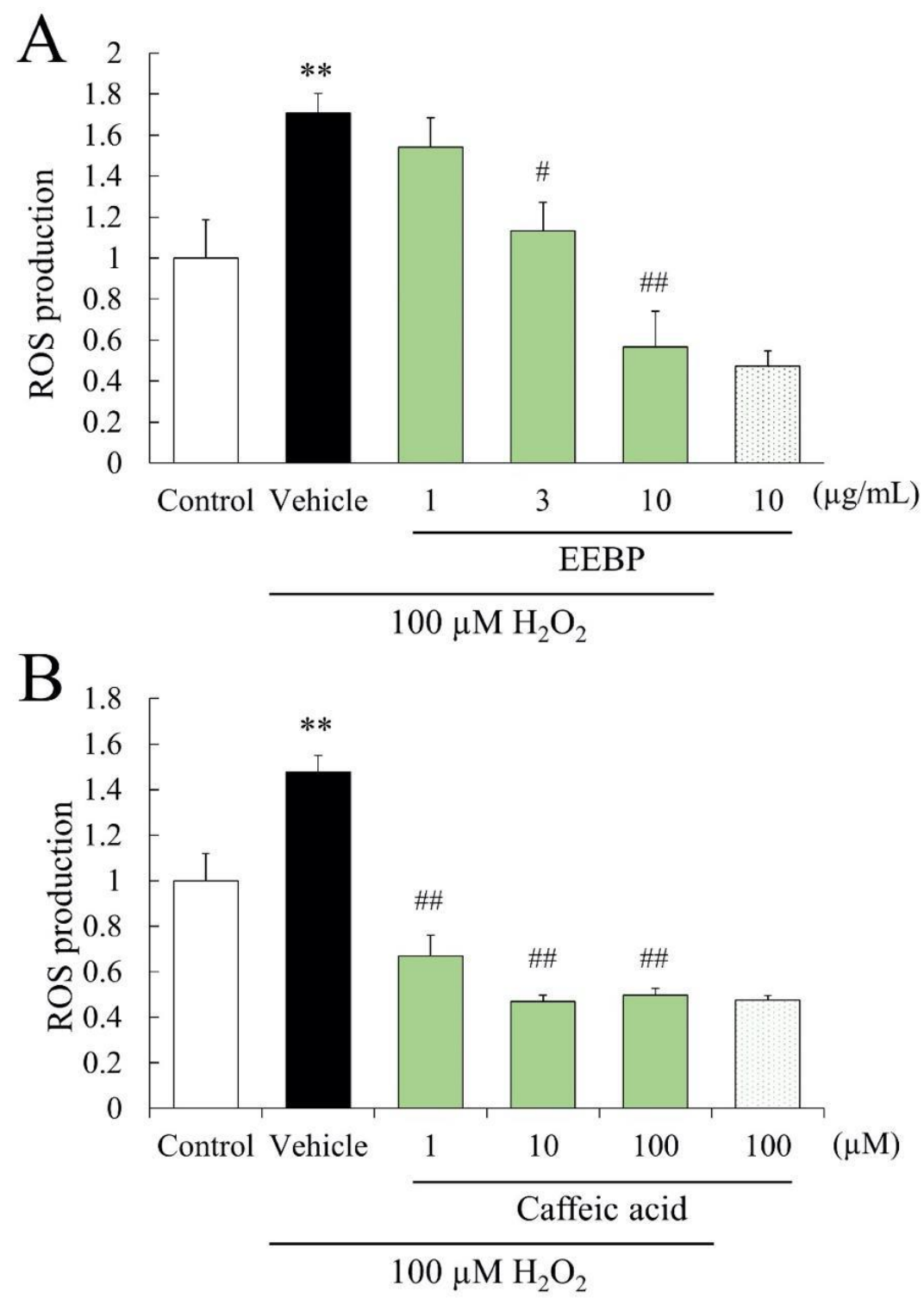

Figure 3. Effects of ethanol-extracted Brazilian green propolis on ROS production in myoblasts following exposure to oxidative stress. Reactive oxygen species (ROS) production was measured using $\mathrm{CM}-\mathrm{H}_{2} \mathrm{DCFDA}$ and is presented as a fold change relative to controls. $\mathrm{C} 2 \mathrm{C} 12$ cells were treated with either ethanol-extracted Brazilian green propolis (EEBP, A), or caffeic acid (B), and incubated in the presence of $100 \mu \mathrm{M} \mathrm{H}_{2} \mathrm{O}_{2}$ for $6 \mathrm{~h}$. Data are shown as the means \pm $\operatorname{SEM}(\mathrm{N}=6) .{ }^{* *} P<0.01$ vs. Control (Student's $t$-test), ${ }^{\#} P<0.05{ }^{\# \#} P<0.01$ vs. Vehicle (Dunnett's test). 
Water-extracted propolis has been reported to activate the Nrf2/Keap1 signaling pathway and upregulate the expression of $\mathrm{HO}-1$, which mediates cytoprotective effects under oxidative stress conditions [16]. HO-1 protein levels were significantly elevated in $\mathrm{C} 2 \mathrm{C} 12$ cells treated with either $10 \mu \mathrm{g} / \mathrm{ml}$ EEBP or $100 \mu \mathrm{M}$ caffeic acid, whereas neither $1 \mu \mathrm{g} / \mathrm{ml}$ EEBP, $100 \mu \mathrm{M}$ trans-ferulic acid, nor $100 \mu \mathrm{M}$ coumaric acid altered HO-1 protein amounts (Fig. 4A and B). As reported previously, $\mathrm{H}_{2} \mathrm{O}_{2}$ exposure increased HO-1 expression levels (Fig. 4A and B). Moreover, HO-1 expression levels were further elevated when $\mathrm{H}_{2} \mathrm{O}_{2}$ treatment was combined with either $10 \mu \mathrm{g} / \mathrm{ml}$ EEBP or $100 \mu \mathrm{M}$ caffeic acid (Fig. 4A and $B)$. These findings suggested that EEBP and caffeic acid can increase the intracellular antioxidative capacity by upregulating the expression of $\mathrm{HO}-1$ in C2C12 cells.
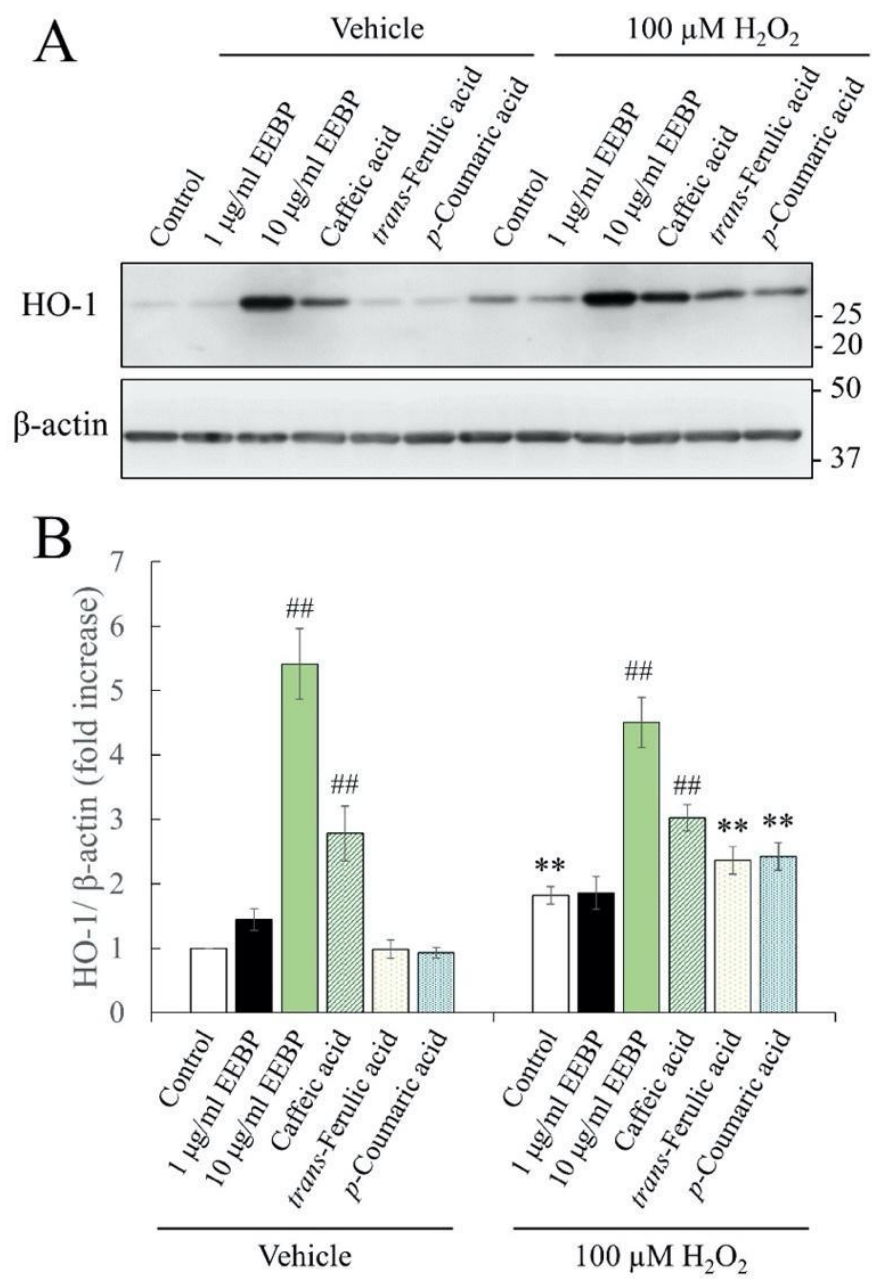

Figure 4. Immunoblotting analysis of myoblast lysates incubated with ethanol-extracted Brazilian green propolis under oxidative stress conditions. The expression of heme oxygenase-1 (HO-1) was analyzed in C2C12 myoblast cell lysates incubated with $\mathrm{H}_{2} \mathrm{O}_{2}$ in the presence or absence of either ethanol-extracted Brazilian green propolis (EEBP; 1 $\mu \mathrm{g} / \mathrm{mL}$ or $10 \mu \mathrm{g} / \mathrm{mL}$ ), $100 \mu \mathrm{M}$ of caffeic acid, $100 \mu \mathrm{M}$ of trans-ferulic acid, or $100 \mu \mathrm{M}$ of $p$-coumaric acid for $6 \mathrm{~h}$. Representative images for the blots and quantitative data are shown in $A$ and $B$, respectively. $\beta$-Actin was used as a loading control. Data are shown as the mean \pm SEM $(N=6) .{ }^{\# \#} P<0.01$ Dunnett's test vs. Control ${ }^{* *} P<0.01$, Student's $t$-test vs.Vehicle (Control, trans-Ferulic acid, $p$-Coumaric acid). 


\section{DISCUSSION}

In the present study, we demonstrated that EEBP exerts a protective effect against $100 \mu \mathrm{M} \mathrm{H} \mathrm{H}_{2} \mathrm{O}_{2}$ induced oxidative stress in $\mathrm{C} 2 \mathrm{C} 12$ cells (Fig. 1). In addition, we demonstrated that one of the EEBP constituents, caffeic acid, ameliorated the decline in cell viability observed following $\mathrm{H}_{2} \mathrm{O}_{2}$ exposure (Fig. 2). Mechanically, EEBP and caffeic acid suppressed ROS production under oxidative stress conditions (Fig. 3). Finally, we found that EEBP and caffeic acid promoted the expression of $\mathrm{HO}-1$ (Fig. 4). Taken together, these results suggested that EEBP promotes HO-1 expression and functions as an antioxidant to protect against oxidative stress. Caffeic acid is likely one of the substances found in EEBP that contributes to these activities.

Propolis contains various constituents, which have antimicrobial, anti-tumorous, antiinflammatory, and antioxidative activities [5]. The constituents of propolis are not consistent among propolis products from different regions; thus, identifying the constituent chemicals that underlie the cytoprotective activities associated with specific types of propolis is an important step. We revealed that caffeic acid might be one of the propolis constituents that exerts a protective effect against oxidative stress in myoblasts (Fig. 2B). Caffeic acid is one of the major chemical ingredients in EEBP, its amount in EEBP is 0.1-0.6 \% (w/w) [20]. In the study for bioavailability in rats, it was reported that the maximum plasma concentration of caffeic acid was reached $250.4 \pm 37.6 \mathrm{ng} / \mathrm{mL}$ (approximately, $1.39 \mu \mathrm{M}$ ) following a single intragastric administration of caffeic acid (10 mg/kg) [21]. Caffeic acid has been reported to markedly reduce intracellular superoxide anion generation in rat vascular smooth muscle cells treated with angiotensin II [22]. In the present model, we demonstrated that caffeic acid suppressed ROS production at a concentration of $1 \mu \mathrm{M}$ (Fig. 3B), suggesting that it might exert its antioxidative effect by oral administration. In addition, caffeic acid elevated the expression of HO-1 with and without oxidative stress (Fig. 4). On the other hand, caffeic acid phenethyl ester (CAPE), a derivative of caffeic acid that is also known to be a chemical constituent of propolis extracts [23], have presented similar biological activities [24], and exerts antioxidative effects through the upregulation of $\mathrm{HO}-1$, which is mediated by Nrf2 [25]. In contrast, p-coumaric acid did not show any significant effects in the myoblast cell culture system (Fig. 2B), although a previous study reported a protective effect against excess light-induced cell damage [26], suggesting that the efficacy and resistance associated with EEBP treatment can vary among different cell types and tissues. While ethanolic extract of propolis was reported to induce apoptosis in a human carcinoma cell line [27], treatment of EEBP without oxidative stress elevated cell viability (Fig. 1B), decreased ROS (Fig. 3A), and increased HO-1 expression (Fig. 4) compared to control in myoblast cells, rather than cytotoxicity. These findings suggest that the biological activity of EEBP should be examined in a suitable cell type for the target tissue of interest.

Sarcopenia is a common disease among elderly individuals and can begin as early as the $4^{\text {th }}$ decade of life. Sarcopenia can be classified as either primary (age-related) or secondary (causal factors other than aging). Mitochondrial function is essential for maintaining skeletal muscle tissues, and the progression of sarcopenia is known to be associated with mitochondrial dysfunction and increased ROS production during aging [2]. Interestingly, Nrf2 regulates not only the expression of antioxidative 
enzymes but also the mitochondrial membrane potential and respiration [28]. Therefore, the effects of EEBP may be mediated through multiple pathways.

Because of the enormous metabolic energy demands, skeletal muscles contain large quantities of myoglobin, a cytoplasmic protein that binds to oxygen on a heme prosthetic group. The physiological relevance of $\mathrm{HO}-1$ in skeletal muscles has long been recognized. Exhaustive exercise and electrical stimulation in rat skeletal muscles induce $\mathrm{HO}-1$ expression to protect muscle tissues from oxidative stress [29]. Moreover, the pharmacological induction of $\mathrm{HO}-1$ has been reported to protect against muscle damage in a murine model of genetic muscle disease, Duchenne muscular dystrophy [30], suggesting that HO-1 might be a therapeutic target for muscular diseases. HO-1 deficiency results in the exhaustion of myosatellite cells [31], indicating that the modulation of HO-1 expression may be able to suppress sarcopenia progression by maintaining satellite cell pools. Further investigation remains necessary to elucidate the effects of EEBP on muscle regeneration.

\section{CONCLUSION}

The present findings indicated that EEBP and its constituent, caffeic acid, exert protective effects against oxidative damage in C2C12 myoblast cell line. EEBP may act as an inducer of HO-1 to protect against oxidative stress in muscles.

List of abbreviations: ARE: antioxidant response element, CCK8: Cell Counting Kit-8, DMEM: Dulbecco's modified Eagle's medium, DMSO: dimethyl sulfoxide, EEBP: ethanol extract of Brazilian green propolis, FBS: fetal bovine serum, HO-1: heme oxygenase-1, Keap1: Kelch-like ECH-associated protein 1, Nrf2: nuclear factor erythroid 2-related factor, ROS: reactive oxygen species.

Author's contributions: All authors contributed to this work. NC designed the research, performed the experiments, and analyzed the results. All authors interpreted the results and designed the research strategy. NC and WO prepared the manuscript.

Competing interests: This work was supported by API Co., Ltd. (Gifu, Japan).

Acknowledgments and Funding: EEBP was gifted from API Co., Ltd. (Gifu, Japan).

\section{REFERENCES:}

1. Cruz-Jentoft AJ, Bahat $G$, Bauer J, Boirie $Y$, Bruyère $O$, Cederholm T, Cooper C, Landi F, Rolland Y, Sayer AA, et al.: Sarcopenia: revised European consensus on definition and diagnosis. Age Ageing. 2019, 48: 601.

2. Szentesi $P$, Csernoch $L$, Dux $L$, and Keller-Pintér $A$ : Changes in Redox Signaling in the Skeletal Muscle with Aging. Oxid. Med. Cell. Longev. 2019, 2019: 4617801.

3. Beccafico S, Puglielli C, Pietrangelo T, Bellomo R, Fanò $G$, and Fulle S: Age-dependent effects on functional aspects in human satellite cells. Ann. N. Y. Acad. Sci. 2007, 1100: 345-352.

4. Carter HN, Chen CCW, and Hood DA: Mitochondria, muscle health, and exercise with advancing age. Physiology. 2015, 30: 208-223.

5. Cornara L, Biagi M, Xiao J, and Burlando B: Therapeutic Properties of Bioactive Compounds from Different Honeybee Products. Front. Pharmacol. 2017, 8: 412.

6. Kujumgiev A, Tsvetkova I, Serkedjieva Y, Bankova V, Christov R, and Popov S: Antibacterial, antifungal, and antiviral activity of propolis of different geographic origin. J. Ethnopharmacol. 1999, 64: 235-240.

7. Paulino N, Teixeira C, Martins R, Scremin A, Dirsch VM, Vollmar AM, Abreu SR, de Castro SL, and Marcucci MC: Evaluation of the analgesic and anti-inflammatory effects of a Brazilian green propolis. Planta Med. 2006, 72: 899-906.

8. Teixeira EW, Message D, Negri G, Salatino A, and Stringheta PC: Seasonal variation, chemical composition and antioxidant activity of Brazilian propolis samples. Evid. Based. Complement. Alternat. Med. 2010, 7: 307315.

9. Ishihara $M$, Naoi $K$, Hashita $M$, Itoh $Y$, and Suzui $M$ : Growth inhibitory activity of ethanol extracts of Chinese and Brazilian propolis in four human colon carcinoma cell lines. Oncol. Rep. 2009, 22: 349-354.

10. Shimazawa M, Chikamatsu S, Morimoto N, Mishima S, Nagai $H$, and Hara $H$ : Neuroprotection by Brazilian Green Propolis against In vitro and In vivo Ischemic Neuronal Damage. Evid. Based. Complement. Alternat. 
Med. 2005, 2: 201-207.

11. Hata T, Tazawa S, Ohta S, Rhyu M-R, Misaka T, and Ichihara K: Artepillin $\mathrm{C}$, a major ingredient of Brazilian propolis, induces a pungent taste by activating TRPA1 channels. PLoS One. 2012, 7: e48072.

12. Nardini M, D'Aquino M, Tomassi G, Gentili V, Di Felice $M$, and Scaccini C: Inhibition of human low-density lipoprotein oxidation by caffeic acid and other hydroxycinnamic acid derivatives. Free Radic. Biol. Med. 1995, 19: 541-552.

13. Crilly MJ, Tryon LD, Erlich AT, and Hood DA: The role of Nrf2 in skeletal muscle contractile and mitochondrial function. J. Appl. Physiol. 2016, 121: 730-740.

14. Al-Sawaf O, Fragoulis A, Rosen C, Keimes N, Liehn EA, Hölzle F, Kan YW, Pufe T, Sönmez TT, and Wruck CJ: Nrf2 augments skeletal muscle regeneration after ischaemiareperfusion injury. The Journal of Pathology. 2014, 234 : 538-547.

15. Kensler TW, Wakabayashi N, and Biswal S: Cell survival responses to environmental stresses via the Keap1Nrf2-ARE pathway. Annu. Rev. Pharmacol. Toxicol. 2007, 47: 89-116.

16. Saito $Y$, Tsuruma K, Ichihara K, Shimazawa M, and Hara $\mathrm{H}$ : Brazilian green propolis water extract up-regulates the early expression level of HO-1 and accelerates Nrf2 after UVA irradiation. BMC Complement. Altern. Med. 2015, 15: 421.

17. Kameyama $\mathrm{T}$, Ohuchi K, Funato $\mathrm{M}$, Ando $\mathrm{S}$, Inagaki $\mathrm{S}$, Sato A, Seki J, Kawase C, Tsuruma K, Nishino I, et al.: Efficacy of Prednisolone in Generated Myotubes Derived From Fibroblasts of Duchenne Muscular Dystrophy Patients. Front. Pharmacol. 2018, 9: 1402.

18. Lee Y-H, Kim D-H, Kim YS, and Kim T-J: Prevention of oxidative stress-induced apoptosis of $\mathrm{C} 2 \mathrm{C} 12$ myoblasts by a Cichorium intybus root extract. Biosci. Biotechnol. Biochem. 2013, 77: 375-377

19. Redza-Dutordoir M, and Averill-Bates DA: Activation of apoptosis signaling pathways by reactive oxygen species. Biochim. Biophys. Acta. 2016, 1863: 2977-2992.

20. Takemura T, Urushisaki T, Fukuoka M, Hosokawa-Muto J, Hata T, Okuda Y, Hori S, Tazawa S, Araki Y, and Kuwata K: 3,4-Dicaffeoylquinic Acid, a Major Constituent of Brazilian Propolis, Increases TRAIL Expression and Extends the Lifetimes of Mice Infected with the Influenza A Virus. Evid Based Complement Alternat Med. 2012, 2012: 946867.

21. Wang SJ, Zeng J, Yang BK, and Zhong YM: Bioavailability of caffeic acid in rats and its absorption properties in the
Caco-2 cell model. Pharm Biol. 2014, 52: 1150-1157.

22. Li P-G, Peng-Gao LI, Jin-Wen XU, Ikeda K, Kobayakawa A, Kayano Y, Mitani T, Ikami T, and Yamori Y: Caffeic Acid Inhibits Vascular Smooth Muscle Cell Proliferation Induced by Angiotensin II in Stroke-Prone Spontaneously Hypertensive Rats. Hypertension Research. 2005, 28: 369-377.

23. Grunberger D, Banerjee R, Eisinger K, Oltz EM, Efros L, Caldwell M, Estevez V, and Nakanishi K: Preferential cytotoxicity on tumor cells by caffeic acid phenethyl ester isolated from propolis. Experientia. 1988, 44: 230232.

24. 2Espíndola KMM, Ferreira RG, Narvaez LEM, Silva Rosario ACR, da Silva AHM, Silva AGB, Vieira APO, and Monteiro MC: Chemical and Pharmacological Aspects of Caffeic Acid and Its Activity in Hepatocarcinoma. Front. Oncol. 2019, 9: 541.

25. Stähli A, Maheen CU, Strauss FJ, Eick S, Sculean A, and Gruber R: Caffeic acid phenethyl ester protects against oxidative stress and dampens inflammation via heme oxygenase 1. Int. J. Oral Sci. 2019, 11: 6

26. Murase H, Shimazawa M, Kakino M, Ichihara K, Tsuruma $\mathrm{K}$, and Hara H: The Effects of Brazilian Green Propolis against Excessive Light-Induced Cell Damage in Retina and Fibroblast Cells. Evid. Based. Complement. Alternat. Med. 2013, 2013: 238279.

27. Czyżewska U, Siemionow K, Zaręba I, and Miltyk W: Proapoptotic Activity of Propolis and Their Components on Human Tongue Squamous Cell Carcinoma Cell Line (CAL-27). PLoS One. 2016, 11: e0157091.

28. Dinkova-Kostova AT, and Abramov AY: The emerging role of Nrf2 in mitochondrial function. Free Radic. Biol. Med. 2015, 88: 179-188.

29. Essig DA, Borger DR, and Jackson DA: Induction of heme oxygenase-1 (HSP32) mRNA in skeletal muscle following contractions. Am. J. Physiol. 1997, 272: C59-67.

30. Chan MC, Ziegler O, Liu L, Rowe GC, Das S, Otterbein LE, and Arany Z: Heme oxygenase and carbon monoxide protect from muscle dystrophy. Skelet. Muscle. 2016, 6: 41.

31. Kozakowska M, Pietraszek-Gremplewicz K, Ciesla M, Seczynska M, Bronisz-Budzynska I, Podkalicka P, Bukowska-Strakova K, Loboda A, Jozkowicz A, and Dulak J: Lack of Heme Oxygenase-1 Induces Inflammatory Reaction and Proliferation of Muscle Satellite Cells after Cardiotoxin-Induced Skeletal Muscle Injury. Am. J. Pathol. 2018, 188: 491-506. 